\title{
CONTENTS
}

TREATIES AND AGREEMENTS

Canada-France-Federal Republic of Germany-ItalyJapan-United Kingdom-United States: Agreement on Guidelines for the Transfer of Equipment and Technology related to Missiles. . . $\cdot \cdot^{\cdot} \cdot \cdot^{\cdot} \cdot$.

Federal Republic of Germany: Pentex Export Consulting $A G$ Draft Agreement on the Rescheduling of Uninsured Trade Debt . . . . . . . $\cdot \cdot^{\cdot}$.

Union of Soviet Socialist Republics-United states: Agreement on Cooperation in the Exploration and Use of Outer space for Peaceful Purposes. . .

United Nations: International Law Commission Draft Articles on Jurisdictional Immunities of States and Their Property. . . . . . . . . . .

JUDICIAL AND SIMILAR PROCEEDINGS

International Centre for settlement of Investment Disputes: Arbitral Tribunal Award in Liberian Eastern Timber Corporation (LETCO) v. The Government of the Republic of Liberia (Recovery of Damages for Breach of a Concession Agreement. United States:

Court of Appeals for the Federal Circuit Decision in Georgetown steel Corporation v. The United States (Countervailing Duties; Application to Nonmarket Economies). . . .

District Court for the southern District of New York Opinion in Liberian Eastern Timber Corporation (LETCO) $\mathrm{v}$. The Government of Republic of Liberia TRecognition of ICSID Award in U.S. Courts; Sovereign Immunity and ICSID Arbitration Clauses; Sovereign Immunity with Respect to Tax Revenues) ... . .

supreme Court Decision in Asahi Metal Industry Co., Ltd. v. Superior Court of California, solano country (Contacts Necessary to Establish State's Jurisdiction over Foreign Defendant; Product Liability in Californial . . . . . . . . . 


\section{LEGISLATION AND REGULATIONS}

Canada: Legislation to Implement the United Nations Convention on the Recognition and Enforcement of Foreign

Arbitral Awards and Legislation on International Commercial

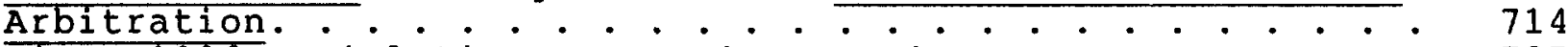

Spain: 1986 Legislation concerning Foreign Investment • . . . 727

Union of Soviet Socialist Republics:

Decree on Joint Enterprises with Western and Developing

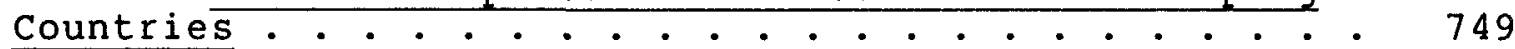

Edict concerning Taxation of Joint Enterprises in

the Soviet Union and Dispute Settlement . • • . . • • . 759

Venezuela: New Foreign Investment and Licensing Regula-
lations and Related Documents. . . . . . . . . . . 760

REPORTS

Philippines: Explanatory Memorandum on Philippine

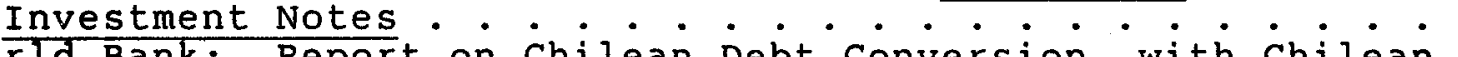

World Bank: Report on Chilean Debt Conversion, with Chilean Rules on Investments with Foreign Debt Instruments and Provision in a Debt Restructuring Agreement for Such Investments. . . . . . . . . . . . . . . . . . . . . .

OTHER DOCUMENTS

General Agreement on Tariffs and Trade: Decisions on Negotiating structure and Plans for the Uruguay Round. . . . organisation for Economic Co-operation and Development:

Council Recommendation for Cooperation in Areas of Potential Conflict between Competition and Trade Policies. $\cdot \cdot \cdot \cdot \cdot \cdot \cdot \cdot \cdot \cdot \cdot \cdot \cdot \cdot \cdot \cdot \cdot \cdot \cdot \cdot \cdot \cdot$

Council Recommendation and Resolution concerning Common Principles of Shipping Policy and Liberalization of Operations Relating to Maritime Transport. .

RECENT ACTIONS REGARDING TREATIES. TO WHICH THE UNITED STATES

IS A PARTY

RECENT ACTIONS REGARDING TREATIES TO WHICH THE UNITED STATES

IS NOT A PARTY . . . . . . . . . . . . . . . . . . . . . . . .

NOTICE OF OTHER RECENT DOCUMENTS (not reproduced) . • • . . . . . 